\title{
非線形群杭係数の変動特性に関する研究 STUDIES ON THE FLUCTUATION CHARACTERISTICS OF NON-LINEAR PILE GROUP COEFFICIENT
}

\author{
土方勝一郎*, 井原和 弘**, 柳下文 雄 ${ }^{* *}$, 間 瀬 辰 也*** \\ Katsuichirou HIJIKATA, Kazuhiro IHARA, Fumio YAGISHITA \\ and Tatsuya MASE
}

\begin{abstract}
This paper presents the fluctuation characteristics of non-linear pile group coefficient. In this study, by evaluating the nonlinear influence coefficients between two piles, we have set up a non-linear pile group coefficient evaluation method which can evaluate non-linearity of soil between and around piles. This method is based on the pile group coefficient expressions which we proposed for the elastic soil in the past. The fluctuation characteristics of non-linear pile group coefficient obtained with this method was confirmed that it corresponds well to that of the analysis results of the three-dimensional finite element method. Based on this knowledge, we elucidated the phenomenon that with pile head displacement increases, the value of the pile group coefficient increases at first, but this value starts to decrease in the later.
\end{abstract}

Keywords : Non-linear pile group coefficient, Pile group coefficient, Influence coefficient between two piles,

Non- linearity of soil, Three-dimensional finite element method

非線形群杭係数, 群杭係数, 影響係数, 地盤非線形, 3 次元有限要素法

\section{1. はじめに}

本研究は、地盤の非線形性を考慮できる群杭係数評価法について 検討し、本方法に基づき地盤の非線形性に起因する群杭係数の変動 特性を明らかにすることを目的とする。

著者等は、均質地盤において正方形に等間隔で配置された群杭を 対象に、地盤と杭の諸元の影響を考慮できる簡便な群杭係数評価式 を提案している ${ }^{1)}$ 。また、この評価法を 2 層地盤に拡張した簡便な 評価式を提案している ${ }^{2)}$ 。護は均質地盤を対象に方向による杭間隔 の違いを考慮できる簡便な群杭係数評価式を提案している ${ }^{3)}$ 。これ らの研究から、群杭係数は杭本数や杭間隔に依存して変化すること が明らかとなってきた。しかしながら、これらの群杭係数評価式は 弾性地盤を対象としたものであり、地盤の非線形性を考慮した群杭 係数の特性に関しては充分な知見が得られていない。

著者等は 3 次元有限要素法(以下 $3 \mathrm{D}-\mathrm{FEM}$ と称する)を用いた解析 により、地盤の非線形性を考慮した群杭係数が、杭頭変位の増加に よってどのように変動するかを検討した ${ }^{4 ）}{ }^{5)}$ 。これらの研究では、 杭頭変位が大きくなるにつれて群杭係数の值は増加する(すなわち 群杭効果は減じる)が、変位が更に進むと頭打ちを生じ、その後群杭 係数の值はむしろ減少に転じる(すなわち群杭効果は増す)特性があ ることを明らかにした。しかしながら、このような群杭係数の変動 特性がどのような要因によって生じるかは明らかではない。 本研究では、文献 2)に示寸弾性地盤を対象とした群杭係数評価式
を非線形地盤に拡張し、比較的簡易に「非線形群杭係数」を評価で きる方法を検討する。そして本方法によれば、先に論じた 3D-FEM 解析で確認した杭頭変位に依存寸る群杭係数の変動特性が説明でき ることを示し、このような変動特性が生じる要因を明らかとする。

なお、本研究では下式に示すように、水平方向の「非線形群杭係 数」は「群杭の杭頭割線剛性」を「 $N p \times$ 単杭の杭頭割線剛性」で除 した值として定義する。ここで、Np は杭本数である。この時、杭 頭の回転は拘束し杭体は線形とする。 非線形群杭係数 $=\frac{\text { 非線形地盤における群杭の杭頭割線剛性 }}{N p \times \text { 非線形地盤における単杭の杭頭割線剛性 }}$

\section{2. 非線形群杭係数の簡便評価法}

\section{2-1. 検討方針}

文献2)に従うと、地盤弾性状態の2 層地盤に関する水平方向群杭係 数 $(\alpha H H)$ は以下のように表すことができる。ここで、Npは杭本数、 $B$ は杭径、Sは杭間隔、Lは杭長である。 $E p$ と $E S$ は杭体と地盤の剛 性である。 $V_{S 1}$ と $V_{S 2}$ は表層と支持層のせん断波速度である。

$$
\begin{aligned}
& \alpha_{H H}=N_{P}^{-a}, \quad a=0.9 f x+a_{0}^{\prime} \\
& f x=\left[0.3+w_{x} \log \left(E_{P} / E_{S}\right)\right](B / S)^{0.75} \\
& w_{x}=0.16-0.35\left(V_{S 2} / V_{S 1}-1\right)^{0.3}(B / L) \\
& a_{0}^{\prime}=\gamma \cdot a_{0}+(1-\gamma) / 5, \quad a_{0}=1 /\left(5+(65 B / L)^{1.5}\right) \\
& \gamma=0.7\left(V_{S 2} / V_{S 1}-1\right)^{0.35} \quad(\gamma \leq 1)
\end{aligned}
$$

\footnotetext{
* 芝浦工業大学 教授・博士 (工学)

** 東電設計(侏) 工修

*** 東電設計侏) 博士 (工学)
}

Prof., Shibaura Institute of Technology, Dr. Eng.

Tokyo Electric Power Services Co., Ltd., M. Eng.

Tokyo Electric Power Services Co., Ltd., Dr. Eng. 
本群杭係数評価式の特色は、群杭係数が杭本数のべき関数で与え られ、このべき数 $(-\boldsymbol{a})$ は (2)式に示寸影響係数 $(f x)$ の関数となって いる点である。したがって、杭間の影響係数を評価することで群杭 係数の值が直接求められる。文献2)に示寸ように、本評価式は杭本 数、杭間隔比及び地盤と杭の剛性比に関し広い範囲で適用可能な式 となっている。なお、影響係数 $(f x)$ とは群杭効果の程度を表す指標 であり、杭頭を連結しない 2 本の杭を考え、1本の杭頭を加力した場 合に生じる他の杭 (以後、受力杭と呼ぶ) の杭頭変位を、加力した杭 (以後、加力杭と呼ぶ) の杭頭変位で除した值として定義される ${ }^{6)}$ 。

本研究では、上記の群杭係数評価式を非線形地盤に拡張する方法 を検討し、これによって非線形地盤における非線形群杭係数の変動 特性を説明することを考えた。具体的には、(2)式に代わる非線形地 盤を対象とする「非線形影響係数」を新たに検討することにより、 (1)式〜(5)式に示寸群杭係数評価式が非線形地盤に対して適用可能 であると仮定し、その適用性について検討した。

\section{2-2. 非線形影響係数の関係式}

本研究では非線形地盤に関する影響係数、すなわち「非線形影響 係数」を以下のように設定した。

文献6)によれば、影響係数は(6)式のように書くことができる。こ こでuは加力杭の杭頭変位を、Vは受力杭の杭頭変位をそれぞれ表す。 両杭は加力方向に並んでおり、杭頭の回転は拘束されているが、水 平方向には独立に動くことができ相互の拘束はないものとする。非 線形地盤に関し(6)式を適用した場合を考え、これを「非線形影響係 数」と呼ぶこととする。

$$
f x=\frac{v}{u}
$$

本研究では、杭周辺地盤の非線形特性は「大局的剛性低下」と「局 所的非線形」に分離することができると仮定する。この概念をFig. 1 に示す。ここで「大局的剛性低下」とは、杭間地盤を含む杭周辺地 盤全体が杭に拘束され変形することにより生じる地盤全体の剛性低 下である。また「局所的非線形」とは, 杭に接触する地盤の局所的 応力集中により生じる地盤の非線形である。本研究では群杭係数の 非線形特性は以上の両者によって支配されると仮定した。

「大局的剛性低下」と「局所的非線形」の両者を考慮した場合の 加力杭と受力杭の杭頭変位を $(u, v)$ 、地盤弾性状態の杭頭変位を

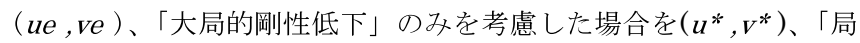
所的非線形」のみ考慮した場合を $\left(u^{* *}, v^{* *}\right)$ と表すこととする。以 上から、地盤の非線形性を考慮した杭頭変位は以下のように書くこ とができる。ここで、倣性状態からの変化分を表す。なお、以 上の 4 組の杭頭変位の内、後半の 2 組は実現象としては存在しない 仮想の状態を想定している。

$$
\begin{aligned}
& u=u e+\Delta u^{*}+\Delta u * * \\
& v=v e+\Delta v^{*}+\Delta v^{* *} \\
& u^{*}=u e+\Delta u^{*} \\
& v^{*}=v e+\Delta v^{*} \\
& u^{* *}=u e+\Delta u * * \\
& v^{* *}=v e+\Delta v^{* *}
\end{aligned}
$$

ここで(13)式を仮定する。本式は「局所的非線形の影響によって 加力杭の杭頭変位が変化しても、受力杭の応答変位は変化しない」
ことを仮定している。この概念をFig. 2に示す。

$$
\Delta v^{* *}=0
$$

これから、以下の関係が成立する。

$$
v=v^{*}
$$

次に「大局的剛性低下」の影響のみを考慮した場合の影響係数を $f x^{*}$ と書くこととする。

$$
f x *=\frac{v^{*}}{u^{*}}
$$

（6)式に(14)式と(15)式を代入すると下式を得る。

$$
f x=\frac{v^{*}}{u}=\frac{v^{*}}{u^{*}} \frac{u^{*}}{u}=f x * \frac{u^{*}}{u}
$$

いま、「大局的剛性低下」と「局所的非線形」の両者を考慮した単 杭の杭頭割線剛性を $K(u)$ 、「大局的剛性低下」のみを考慮した仮想 的な杭頭割線剛性を $K^{*}\left(u^{*}\right)$ と表すと以下の関係が成立する。ここで、 $Q$ は杭頭水平作用力である。

$$
\begin{aligned}
& Q(u)=K(u) \cdot u \\
& Q\left(u^{*}\right)=K^{*}\left(u^{*}\right) \cdot u^{*}
\end{aligned}
$$

同一の杭頭作用力 $Q$ を考えて、(17)式と(18)式を等置すると下式 を得る。

$$
\frac{u^{*}}{u}=\frac{K(u)}{K^{*}\left(u^{*}\right)}
$$

これを(16)式に代入すると(20)式を得る。ここで、同一の杭頭作用 力 $Q$ に対し、加力杭の応答值 $u$ と $u^{*}$ は異なる值であることに注意 を要する。両者の差分が「局所的非線形」の寄与分となる。なお 2-3 の Fig.5にはこの関係を図示寸る。

$$
f x=f x^{*} \frac{K(u)}{K^{*}\left(u^{*}\right)}
$$

(20)式を便宜的に初期剛性値 $\left(K(0)=K^{*}(O)\right)$ で基準化すると下式の ように表すことができる。

$$
f x=f x^{*} \frac{K(u) / K(0)}{K^{*}\left(u^{*}\right) / K^{*}(0)}
$$

(21)式が(7)〜(13)の仮定から導かれた「大局的剛性低下」と「局 所的非線形」の両者を考慮した「非線形影響係数」の基本式である。

なお、杭周辺地盤の「大局的剛性低下」には本来、杭の変形に加 えて地盤震動による寄与分も存在するが、本研究では一般的な杭頭 載荷の検討同様、地盤震動の影響は考慮していない。

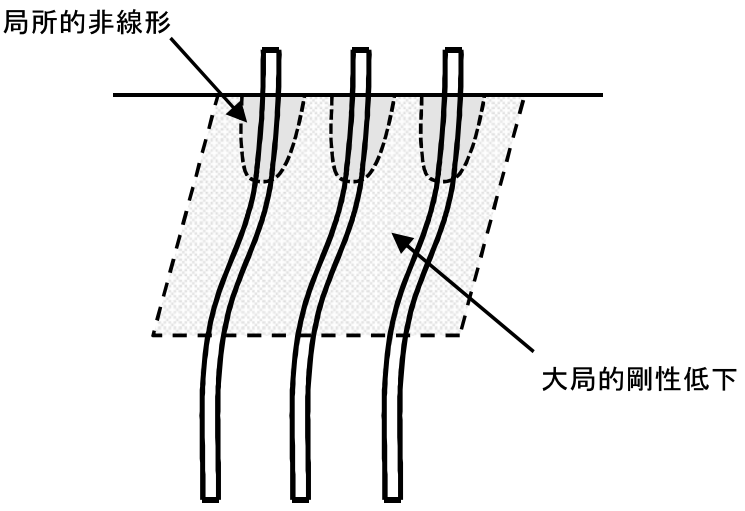

Fig. 1 Non-linear stiffness degradation of local and entire soil 


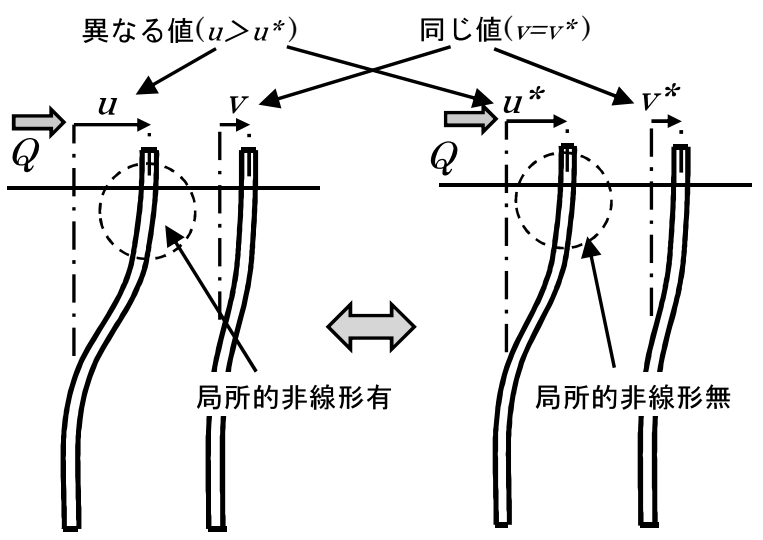

Fig. 2 Assumptions of the non-linear influence coefficient

\section{2-3. 非線形影響係数の計算}

(1) $f x *$ 評価方法

（21)式に用いる「大局的剛性低下」の影響のみを考慮した非線形 影響係数 $f_{x}^{*}$ \%評価方法を以下に示す。

$f_{X}$ *は杭周辺地盤全体の剛性低下を考慮した $E s$ を(2)式に適用す ることで評価できる。このため、杭頭変位 $u^{*}$ によって生じる杭周 辺地盤全体のせん断ひずみを近似的に評価し、これと土質試料のせ ん断試験を模擬した 3D-FEM 解析結果から評価した「せん断剛性低 下率一せん断ひずみ曲線 $\left(G / G_{0} \sim Y\right.$ 曲線 $) 」$ を関係付けることで $f_{X}$ * を計算することとした。具体的な計算方法を以下に示す。

弾性支承上のはり理論により、弾性地盤に関する単杭の不動点深 さ $L$ は以下のように与えられる ${ }^{7)}$ 。ここで、Ep は杭剛性、Ip は杭 の断面 2 次モーメント、 $S_{H}$ は地盤反力係数に杭径を乗じた值である。

$$
L=\frac{3 \pi}{4}\left(\frac{4 E_{P} I_{P}}{S_{H}}\right)^{\frac{1}{4}}
$$

杭の拘束効果によって、地表面位置の杭頭の変位量と杭周辺地盤 の変位量は同一であり、更に杭の不動点深さは「大局的剛性低下」 によって大きくは変化しないと仮定すると、杭頭変位 $u^{*}$ と杭周辺地 盤のせん断ひずみ $Y$ は(23)式のように近似的に関係付けることがで きる。この概念を Fig. 3 に示す。ここで、(23)式に用いる $L$ の值は 地盤の初期剛性を用い(22)式から計算する。

$$
\gamma=u^{*} / L
$$

この $Y$ と土質試料のせん断試験を模擬した $3 \mathrm{D}-\mathrm{FEM}$ 解析から評 価した $\left(G / G_{0} \sim Y\right.$ 曲線 $)$ を用いることで、 $u^{*}$ に対応した地盤のせん 断剛性值を評価することができる。なお、杭頭変位に応じて $L$ の值 は変化するが、初期剛性に基づく $L$ を用い $Y$ を評価しても、地盤の せん断剛性值評価に与える影響は小さいことを別途確認している。 更に、(24)式の関係を用いると、 $\left(u^{*} \sim Y \sim G \sim E S\right)$ を関係付けるこ とができる。

$$
E_{S}=2(1+v) G
$$

本研究では、以上の手順で $u$ *に対応した ES の值を求め、これを (2)式に代入することで $f x$ *計算することとした。この $f_{x} *$ により、 (1)式〜(5)式から「大局的剛性低下」の影響のみを考虑した非線形群 杭係数を計算することができる。

\section{(2) 割線剛性の評価方法}

（21）式に用いる初期剛性で規準化した割線剛性の評価方式を以下

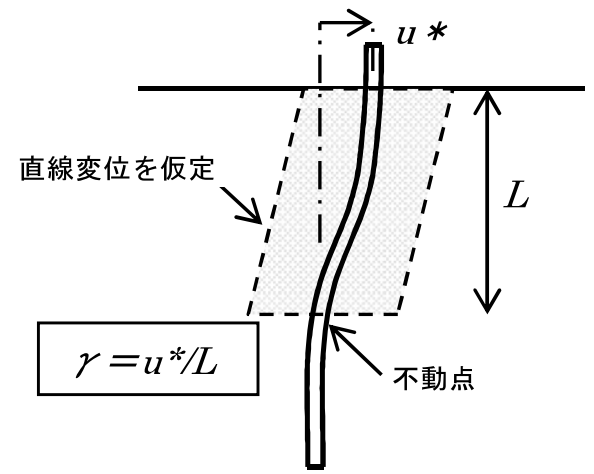

Fig. 3 Evaluation method for the shear strain of entire stiffness degradation

に示寸。

$K(u) / K(0)$ は「大局的剛性低下」と「局所的非線形」の両者を考慮 した単杭の杭頭における荷重变形関係 $(Q(u) \sim u$ 曲線 $)$ を何らかの方 法で評価することにより、杭頭変位 $u$ に対応した割線剛性 $K(u)$ と初 期剛性 $K(0)$ の)比として与えられる。本研究では、この值は後述する ように単杭の3D-FEM解析から評価することとした。

一方、 $\left(K^{*}\left(u^{*}\right) / K^{*}(0)\right)$ は、「局所的非線形」を除外した「大局的 剛性低下」のみの杭頭剛性から与えられるため、3D-FEM 解析から は直接求めることができない。そこで、次のように近似的に求める こととした。

いま均質地盤の長い杭を考えると、杭頭剛性は弾性支承上のはり 理論に基づき(25)式のように与えられる ${ }^{6)}$ 。ここで、 $S_{H}\left(u^{*}\right)$ は杭頭 変位 $u$ *に対応する地盤反力係数に杭径を乗じた值である。

$$
K^{*}\left(u^{*}\right)=\left[4 E_{p} I_{p}\right]^{\frac{1}{4}}\left[S_{H}\left(u^{*}\right)\right]^{\frac{3}{4}}
$$

ここで、 $u^{*}=0$ における初期剛性によって(25)式を基準化すると、以 下のように表すことができる。

$$
\frac{K^{*}\left(u^{*}\right)}{K^{*}(0)}=\left[\frac{S_{H}\left(u^{*}\right)}{S_{H}(0)}\right]^{\frac{3}{4}}
$$

ところで、 $S_{H}$ はFrancisのばね ${ }^{8)}$ によって以下のように与えられ る。ここで、恃地盤のポアソン比である。

$$
S_{H}=\frac{1.3 E s}{1-v^{2}}\left[\frac{E s B^{4}}{E_{p} I_{p}}\right]^{\frac{1}{12}}
$$

また、(24)式に示すように ES と $G$ には比例関係が成立することか ら、(27)式より以下の関係を導くことができる。ここで、G(u*)は(23) 式によって与えられる $\gamma$ に対応した地盤のせん断剛性值である。

$$
\frac{S_{H}\left(u^{*}\right)}{S_{H}(0)}=\left[\frac{E s\left(u^{*}\right)}{E s(0)}\right]^{\frac{13}{12}}=\left[\frac{G\left(u^{*}\right)}{G_{0}}\right]^{\frac{13}{12}}
$$

(26)式(28)式から $\left(K^{*}\left(u^{*}\right) / K^{*}(0)\right)$ の值は(29)式のようになる。

$$
\frac{K^{*}\left(u^{*}\right)}{K^{*}(0)}=\left[\frac{G\left(u^{*}\right)}{G_{0}}\right]^{\frac{13}{16}}
$$

本研究では、(29)式に用いるせん断地盤剛性は、2-3(1)項に示した 土質試料のせん断試験を模擬した 3 D-FEM解析結果を用いることと した。 


\section{(3) $f_{X}$ の計算}

以上で求めた $f_{x}^{*} 、(K(u) / K(0))$ 及び $\left(K^{*}\left(u^{*}\right) / K^{*}(0)\right)$ を用いて $(21)$ 式に示す非線形影響係数 $f x$ を計算する手順を以下に示す。

計算に際しては、まず Fig. 4 に示す $\left(Q^{*}\left(u^{*}\right) / K^{*}(0) \sim u^{*}\right)$ 曲線を 作成する。ここで、 $Q^{*}\left(u^{*}\right) / K^{*}(0)$ は「大局的剛性低下」のみを考 慮した場合の杭頭初期剛性で基準化した杭頭作用力であり、 $u$ *はそ の時の杭頭変位である。 $\left(Q^{*}\left(u^{*}\right) / K^{*}(0) \sim u^{*}\right)$ 曲線を作成するには、

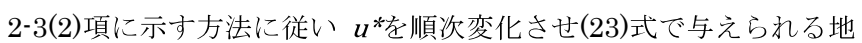
盤のせん断ひずみを順次計算する。この歪みに対応した地盤のせん 断岡性 $G\left(u^{*}\right)$ を土質試料のせん断試験を模擬した $3 \mathrm{D}-\mathrm{FEM}$ 解析から 計算し、(29)式から $\left(K^{*}\left(u^{*}\right) / K^{*}(0)\right)$ を計算する。これから(30)式の 関係を用い Fig. 4 に示寸 $\left(Q^{*}\left(u^{*}\right) / K^{*}(0) \sim u^{*}\right)$ 曲線を作成する。

$$
\frac{Q^{*}\left(u^{*}\right)}{K^{*}(0)}=\frac{K^{*}(u)}{K^{*}(0)} u^{*}
$$

次に Fig. 5 に示すように、上に示した $\left(Q^{*}\left(u^{*}\right) / K^{*}(0) \sim u^{*}\right)$ 曲線と、 単杭の $3 \mathrm{D}-\mathrm{FEM}$ 解析から求めた $(Q(u) / K(0) \sim u)$ 曲線を重㸚書く。 なお、 $\left(Q^{*}\left(u^{*}\right) / K^{*}(0) \sim u^{*}\right)$ 曲線では、「大局的剛性低下」のみが、 3D-FEM 解析では「大局的剛性低下」と「局所的非線形」の両者が 考慮されている。

(21)式の影響係数評価に用いる割線剛性 $K(u) / K(0)$ 及び $K^{*}\left(u^{*}\right) /$ $K^{*}(0)$ の值は、同一の杭頭作用力に対応する值であることに着目し、 Fig. 5 に基づき以下の手順で(21)式を計算することとする。

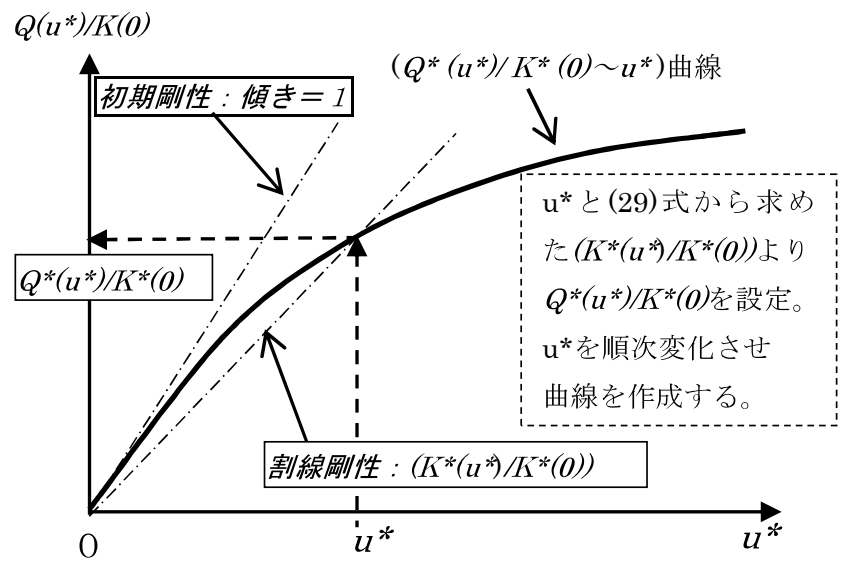

Fig. $4 \quad\left(Q^{*}\left(u^{*}\right) / K^{*}(0) \sim u^{*}\right)$ curve

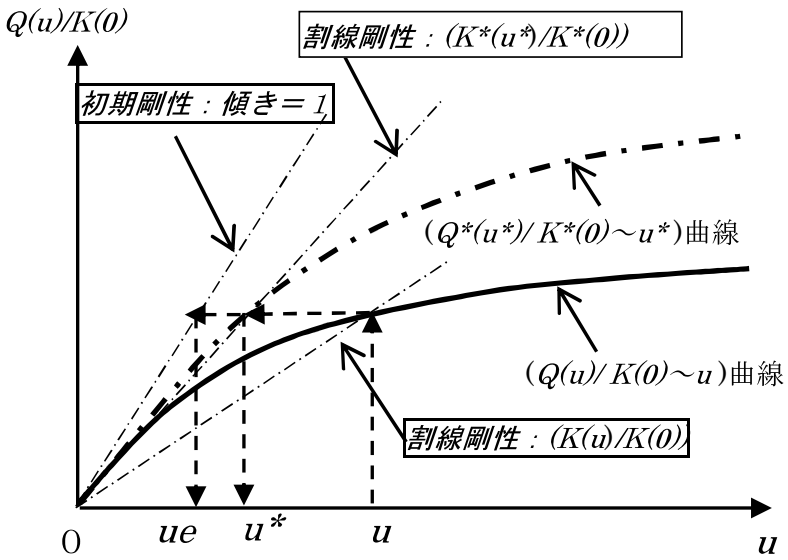

Fig. $5\left(Q^{*}\left(u^{*}\right) / K^{*}(0) \sim u^{*}\right)$ and $(Q(u) / K(0) \sim u)$ curve
まず $(Q(u) / K(0) \sim u)$ 曲線で任意の杭頭変位 $u$ に対応した $Q(u) / K(0)$ 及び割線剛性 $(K(u) / K(0))$ を読み取る。更に $\left(Q^{*}\left(u^{*}\right) / K^{*}(0) \sim u^{*}\right)$ 曲線 において、同一の杭頭荷重 $Q(u) / K(0)$ に対応した、杭頭変位 $u^{*}$ と割 線剛性 $K^{*}\left(u^{*}\right) / K^{*}(0)$ を読み取る。以上の手順で読み取った基準化 した割線剛性值と 2 - 3(1)項で論じた「大局的剛性低下」の影響の みを考慮した非線形影響係数 $f x^{*}$ を(21)式に代入することで、「大局 的剛性低下」と「局所的非線形」の両者を考慮した非線形影響係数 $f_{x}$ を計算することができる。この $f x$ を用いて(1)式〜 (5)式から非線 形群杭係数を計算する。

\section{3. 非線形影響係数の比較検討}

本章では、2章に示した「大局的剛性低下」と「局所的非線形」 の両者を考慮した非線形影響係数 $f x$ 、及び「大局的剛性低下」のみ を考えた場合の非線形影響係数 $f x$ を計算する。更に「局所的非線 形」のみを考えた場合の非線形影響係数を $f x^{*}$ として求め、この 3 者の比較を試みる。

「局所的非線形」のみを考えた場合の非線形影響係数 $f x *$ *の計算

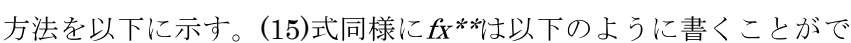
きる。

$$
f x * *=\frac{v^{* *}}{u^{* *}}
$$

ここで、(32)式に示すように地盤弾性状態に対応した影響係数を定 義する。eは地盤弾性状態を表す。

$$
f x e=\frac{v e}{u e}
$$

（12)式、(13)式及び(32)式から(31)式は以下のように表される。

$$
f x^{* *}=\frac{v^{* *}}{u e} \cdot \frac{u e}{u * *}=\frac{v e}{u e} \frac{u e}{u^{* *}}=f x e \frac{u e}{u^{* *}}
$$

更に、（7)式(9)式及び(11)式から $\Delta u^{*} 、 \Delta u^{* *}$ 消去し、(33)式の分母 を書き直すと(34)式を得る。

$$
f x^{* *}=f x e \frac{u e}{u e+u-u^{*}}
$$

ここで、影響係数の定義から ue、 $u 、 u$ *法同一の杭頭荷重に対応す る值であることに着目すると以下の関係が成立する。

$K(0) \cdot u e=K(u) \cdot u=K^{*}\left(u^{*}\right) \cdot u^{*}$

したがって(34)式は以下のように書き直すことができる。

$$
f x^{* *}=f x e \frac{1}{1+\frac{K(0)}{K(u)}-\frac{K^{*}(0)}{K^{*}\left(u^{*}\right)}}
$$

(36)式が「局所的非線形」のみを考えた場合の非線形影響係数 $f x^{* *}$ の基本式である。(36)式を用いると、Fig. 5 において同一の縦軸 の值から読み取った $u 、 u$ *対応する割線剛性の值と、(2)式から計 算した地盤弾性状態の影響係数 $f x e$ の值から $f^{*}$ をを求めることがで きる。

以上に論じた非線形影響係数 $\left(f x 、 f x^{*} 、 f x^{* *}\right)$ を比較した。Table 1 には検討に用いた地盤物性を示す。杭は杭径 $1.5 \mathrm{~m}$ 、厚さ $15 \mathrm{~mm}$ の鋼管杭とし、杭長は支持地盤への貫入長 $5 \mathrm{~m}$ を含め $30 \mathrm{~m}$ とした。 非線形影響係数の評価に用いる $(Q(u) / K(0) \sim u)$ 曲線は、単杭の $3 \mathrm{D}-\mathrm{FEM}$ 解析から計算した。単杭の 3D-FEM 解析モデルを Fig. 6 に示す。杭はシェル要素でモデル化し、杭周辺地盤とは接触・剥離・ 
摩擦を考慮した。地盤は表層の厚さ $25 \mathrm{~m}$ の砂地盤とし、表層地盤と 支持地盤はそれぞれ一様な物性としソリッド要素でモデル化した。 また、対称条件を考慮し、解析モデルは $1 / 2$ モデルとし側方及びモ デル底面以梁には無限要素を用いた。解析には Abaqus ${ }^{9)}$ を使用し、 地盤は Mohr-Coulomb 弾塑性モデルとして非関連流れ則を適用し、 全応力解析を実施した。なお, 解析に当たっては自重解析を行い初 期応力状態とした。

また、 $\left(Q(u) * / K^{*}(0) \sim u^{*}\right)$ 曲線は、土質試料のせん断試験を模擬し た 3D-FEM 解析から $\left(G / G_{0} \sim \gamma\right)$ 曲線を計算した上で、2-3(3)項に示 す方法で計算した。(G/G0〜 $)^{\gamma}$ 曲線の計算は単杭同様 $\mathrm{Abaqus}^{9)}$ を 使用した。計算結果を Fig. 7 に示す。

杭間隔比が 2.5 の非線形影響係数 $\left(f x 、 f x^{*} 、 f x^{* *}\right)$ の計算結果の比 較を Fig. 8 に示寸。本図から認められることは以下の 3 点である。 (1)「大局的剛性低下」の影響のみを考慮した「非線形影響係数 $\left(f x^{*}\right) 」$ は杭頭変位が増加するほど、值が若干増加する特性を示す。これ は地盤の剛性が低下寸るに連れ、影響係数の值が大きくなる $(2)$ 式の特性に起因している。

(2)「局所的非線形」の影響のみを考慮した「非線形影響係数 $\left.\left(f^{* *}\right)\right\rfloor$ は杭頭変位が増加するほど、減少する特性を示す。これは(34)式 の特性を反映するものであり、 $u$ と $u^{*}$ 差が大きくなるほど、す なわち「局所的非線形」が増大寸るほど影響係数の值は小さくな る特性に起因している。

(3)本研究で設定した $(21)$ 式に示寸「非線形影響係数 $(f \boldsymbol{x}) 」$ は、杭頭 変位が増大すると減少する傾向を示すが、その後増加に転じる。 このような特性は、杭頭変位が増加すると、まずは(2)に示した「局 所的非線形」の効果が発現し、遅れて(1)に示した「大局的剛性低 下」の効果が発現することに対応していると考えられる。

以上に論じた「非線形影響係数」の変動が、群杭係数にどのように 影響するかは次章で検討する。

Table 1 Specifications of the soil

\begin{tabular}{|c|c|c|c|}
\hline \multicolumn{2}{|c|}{ 地盤種別 } & 表層部 (砂質土) & 支持層 \\
\hline 弾 & $\rho\left(\mathrm{t} / \mathrm{m}^{3}\right)$ & 1.8 & 1.8 \\
\cline { 2 - 4 } 性 & $V \mathrm{~V}(\mathrm{~m} / \mathrm{s})$ & 200 & 500 \\
\cline { 2 - 4 } 特 & ポアソン比 & 0.4 & 0.4 \\
\cline { 2 - 4 } 性 & ヤング係数 $\left(\mathrm{MN} / \mathrm{m}^{2}\right)$ & 201.6 & 1260.0 \\
\hline \multirow{2}{*}{ 塑 } & $\mathrm{C}\left(\mathrm{kN} / \mathrm{m}^{2}\right)$ & 1 & - \\
\cline { 2 - 4 } 性 & $\phi$ & $35^{\circ}$ & - \\
\cline { 2 - 4 } 特 & 降伏条件 & Mohr-Coulomb & - \\
\cline { 2 - 4 } 性 & 流れ則 & 非関連 (文献 12) & - \\
\cline { 2 - 4 } & 降伏後膨張角 & $0.1 \phi$ & - \\
\hline
\end{tabular}

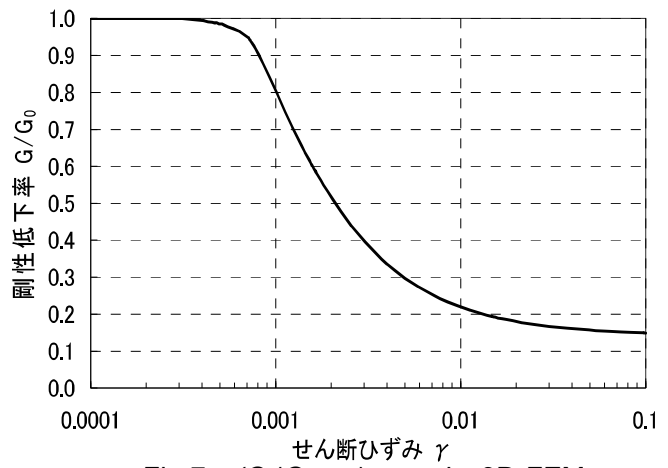

Fig.7 $\left(G / G_{0} \sim \gamma\right)$ curve by 3D-FEM

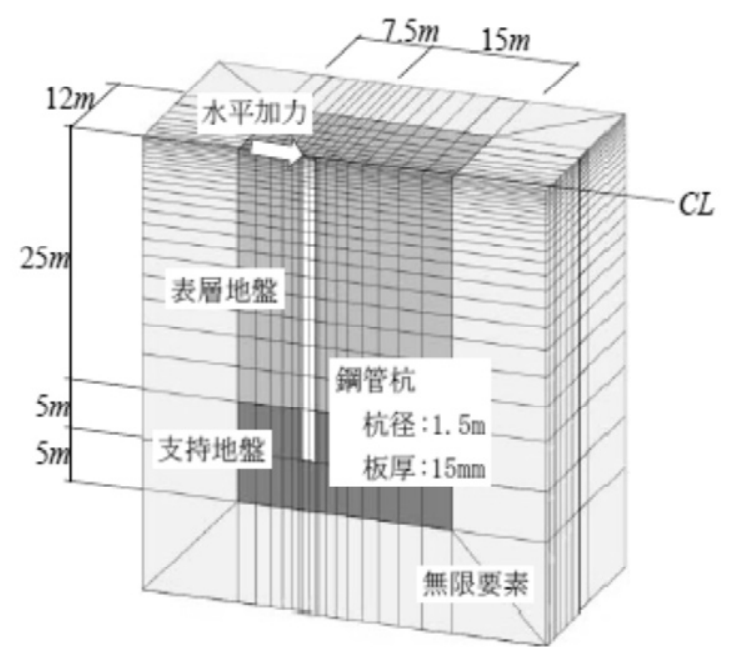

Fig.6 Analysis model of the single pile

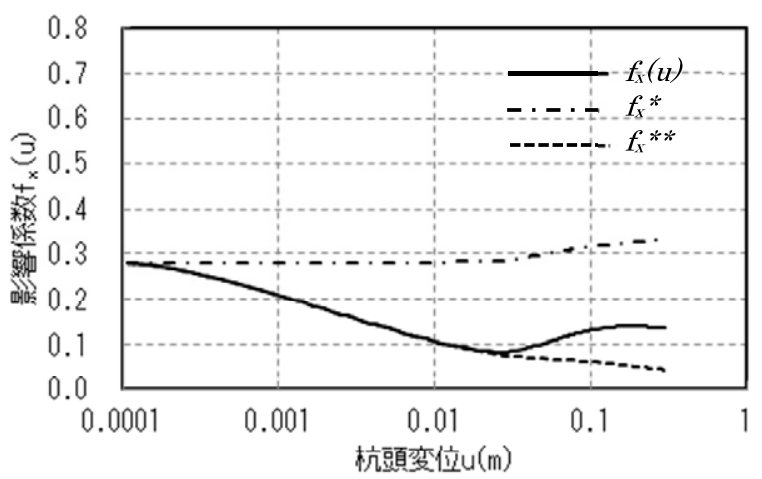

Fig.8 Comparison of each influence coefficient

\section{4. 群杭係数の検討と考察}

3 章に示した $\left(f_{x} 、 f_{x}{ }^{*} 、 f_{X}^{* *}\right)$ を用いて、(1)式〜 (5)式によって非 線形群杭係数を計算した。なお(1)式の $a_{0}^{\prime}$ は「大局的剛性低下」を 考慮すると值が最大 1 割程度変動するが、その影響は小さいことを 別途確認しており、ここでは表層地盤の初期值を用いた一定值とし た。杭と地盤の条件は Table 1 及び Fig. 6 と同一である。群杭は 9 本杭、25 本杭の等間隔正方形配置とした。Fig.9には杭間隔比が 2.5 の計算結果を、Fig.10には杭間隔比 6.0 の計算結果を示す。また、 両図には 3D-FEM 解析から直接計算した非線形群杭係数を $\square \diamond に$ よりあわせて示す。本図から以下の 4 点が分かった。

(1)(21)式に示寸 $f x$ を用いて計算した「非線形群杭係数」は 3D-FEM 解析結果と定性的な傾向は同じである。具体的には、両者とも杭 頭変位が大きくなるにつれ群杭係数の值が増加し、その後減少に 転じる傾向を呈しており特性は調和的である。なお、今回 3D-FEM から得られた群杭係数の変動特性は文献 4)、文献 5)、 文献 10)等においても認められている。

(2) $f_{x}$ *を用い「大局的剛性低下」の影響のみを考慮した非線形群杭 係数は杭頭変位が増大寸ると值が単調に低下寸る傾向が認められ

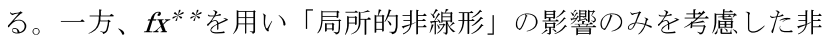
線形群杭係数は杭頭変位が増大寸ると值が単調に増加する傾向が 認められる。 $f^{*}$ 、 $f_{x}^{* *}$ 単独で用いた評価結果は、3D-FEM解 析結果と定性的な傾向は一致しない。3D-FEM解析の特性を再現 するには「大局的剛性低下」と「局所的非線形」の両者の影響を 
考慮する必要がある。

(3)以上の (1)(2)に示寸特性と Fig.8から、「非線形影響係数」と「非線 形群杭係数」の関係は以下のように理解寸ることができる。杭頭 変位が進むと、まずは杭に接触する地盤の局所的応力集中による 地盤非線形(局所的非線形)が先行し、「非線形影響係数」の值が低 減する。これにより「非線形群杭係数」の值は増加する。更に杭 頭変位が進行すると、杭間を含む杭周辺地盤全体が杭に拘束され 変形することにより生じる地盤全体の剛性低下 (大局的剛性低下) が発現し、「非線形影響係数」の值は増加する。これにより「非線 形群杭係数」の值は低減寸る。

(4)今回設定した評価法は、9本杭に比較し25本杭の方が、また杭間 隔比6.0に比較し 2.5 の方が3D-FEMの解析との対応が良い。これ は杭本数が増加する程、また杭間隔比が小さい程、杭による地盤 の拘束効果が強く働き、杭周辺地盤の変形が杭の変形と等しくな る傾向が明瞭に表れ、本研究で仮定した「大局的剛性低下」に近 い地盤の変形状態が出現するためと推定される。

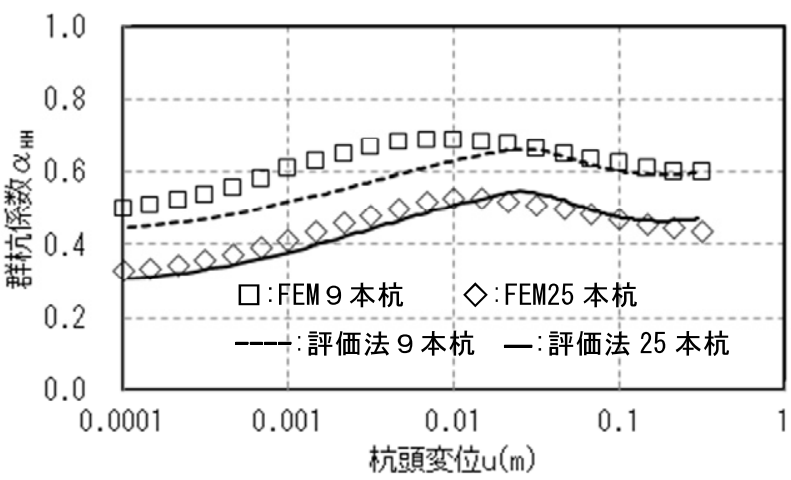

Fig.9(1) Non-linear pile group coefficient with $\mathrm{fx}(\mathrm{S} / \mathrm{B}=2.5)$

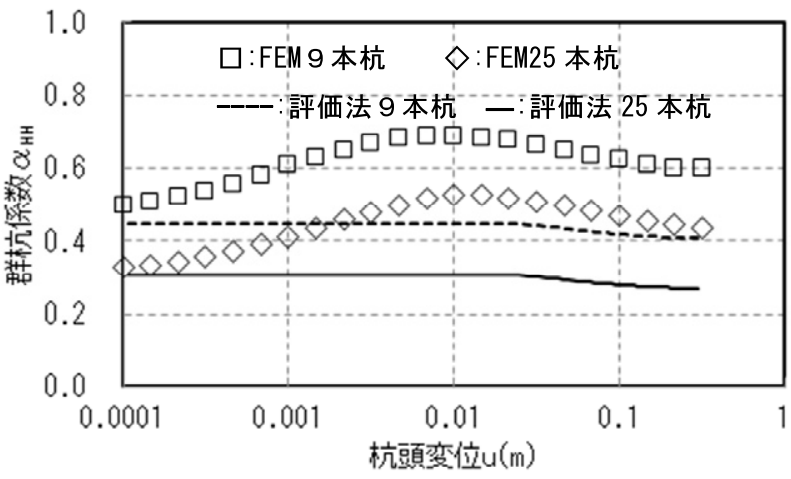

Fig.9(2) Non-linear pile group coefficient with $\mathrm{fx}^{*}(\mathrm{~S} / \mathrm{B}=2.5)$

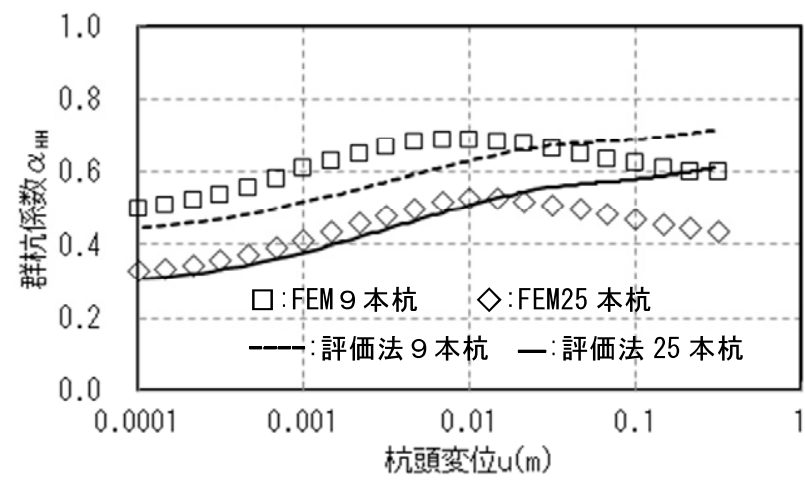

Fig.9(3) Non-linear pile group coefficient with $\mathrm{fx}^{\star \star}(\mathrm{S} / \mathrm{B}=2.5)$

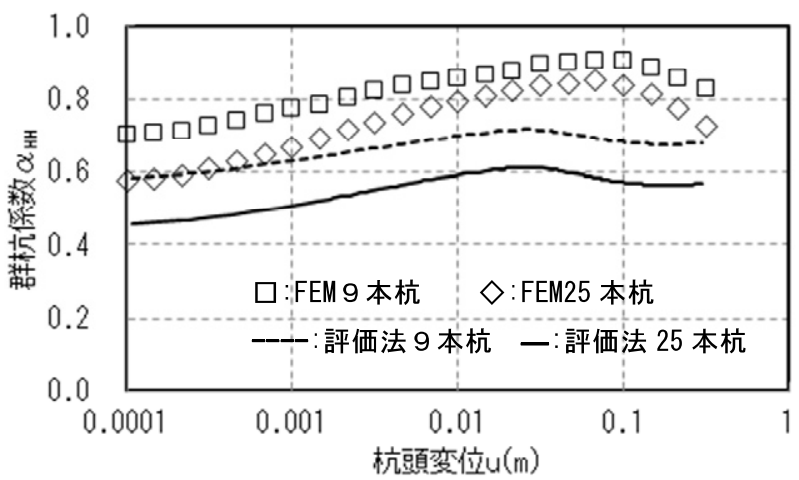

Fig.10(1) Non-linear pile group coefficient with $\mathrm{fx}(\mathrm{S} / \mathrm{B}=6)$

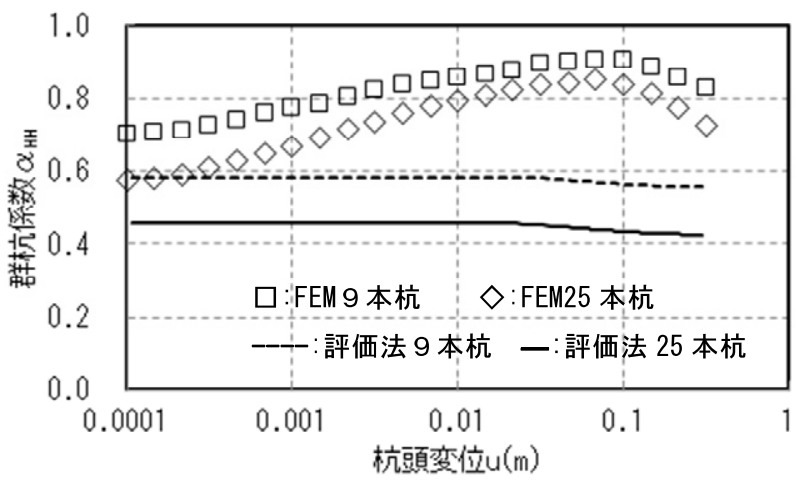

Fig.10(2) Non-linear pile group coefficient with $\mathrm{fx}^{*}(\mathrm{~S} / \mathrm{B}=6)$

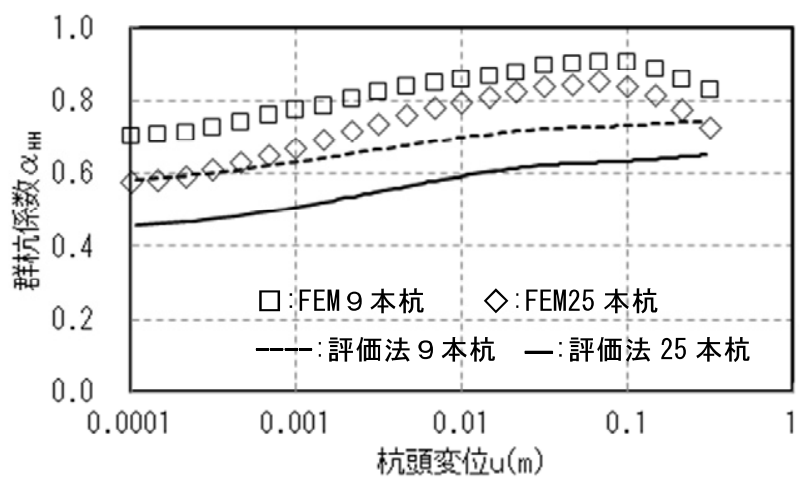

Fig.10(3) Non-linear pile group coefficient with $\mathrm{fx}^{* \star}(\mathrm{S} / \mathrm{B}=6)$

\section{5. まとめ}

本研究では、弾性地盤を対象とした既往の群杭係数評価式に(21) 式の非線形影響係数を適用することにより、非線形地盤の群杭係数 の変動特性を定性的に説明できることを確認した。なお、杭本数が 多く、杭間隔比が小さいほど、本研究で設定した非線形群杭係数評 価法は 3D-FEM 解析との対応が良い傾向が認められた。これは上 記の条件ほど本研究で仮定した「大局的剛性低下」に近い地盤の变 形状態が出現するためと考えられる。

本評価法を用いた検討から「非線形群杭係数」の变動特性は以下 のように理解できることが分かった。

(1)杭頭変位が進むと、まずは杭に接触する地盤の局所的応力集中に よる地盤非線形(局所的非線形)が先行する。これは「非線形影響 係数」の值を低減させ、「非線形群杭係数」を増加させる方向に作 用する。すなわち、群杭効果は減じることとなる。 
(2)杭頭変位が更に進行すると、杭間を含む杭周辺地盤全体が杭に拘 束され変形することにより生じる地盤全体の剛性低下（大局的剛 性低下）が発現する。これは「非線形影響係数」の值を増加させ、

「非線形群杭係数」を低減させる方向に作用する。すなわち、群 杭効果は増すこととなる。

(3)以上から杭頭变位が進むと、当初は増加する傾向を示した非線形 群杭係数に頭打ちが生じ、その後減少に転じるようになる。この ような特性から「非線形群杭係数」值の変動は抑制され、比較的 安定的な值を示す。

なお、本論文は文献 11）に示す既発表論文に基づき、非線形群杭 係数評価式を全面的に見直し新たにまとめ直したものである。

\section{謝辞}

3D-FEM 解析は鹿島建設株式会社が実施したものです。ここに記 して感謝の意を表します。

\section{参考文献}

1）土方勝一郎, 今村晃, 柳下文雄, 富井隆, 小山桂介: 群杭係数の評価方法に 関する研究, 日本建築学会構造系論文集第 476 号, pp.57-66, 1995.10

2) 土方勝一郎, 杉山達也, 石田智昭, 柳下文雄, 間瀬辰也：2 層地盤を対象 とした水平方向の群杭係数評価式に関する研究, 日本建築学会構造系論 文集第 604 号, pp.63-70, 2006.6

3）護雅史・森川和彦 : 加振方向を考慮した群杭効率の推定式の提案, 第 3 回 日本地震工学会発表会, pp.416-417, 2004

4) 土方勝一郎, 杉山達也, 石田智昭, 伊東賢伸, 藤原一成, 橋本尚之, 酒向裕 司,鈴木篤, 澤田祥平他 : 3D-FEM に基づく群杭地盤ばねの非線形特性, その 1 , その 2 , その 3 日本建築学会大会学術講演梗概集 構造 I, pp.435-440, 2006

5）薮内彰夫, 土方勝一郎, 今村晃, 徳光亮一, 酒向裕司,柳下文雄他: $3 \mathrm{D}-\mathrm{FEM}$ に基づく群杭地盤ばねの非線形特性, その 4 , その 5 , その 6 , 日本建築学 会大会学術講演梗概集 構造 I, pp.623-628, 2007

6) 土方勝一郎, 柳下文雄, 富井隆 : 群杭の動的インピーダンス簡便評価法, 日本建築学会構造系論文集第 455 号, pp.73-82, 1994.01

7）日本建築学会 : 建築基礎構造設計指針 2001 改定, p.270, 2001

8) Francis. A. J: Analysis of Pile Groups with Flexural Resistance, Pro.ASCE. Vol.90. NoSM2, 1964

9) Abaqus ver.6.7.1, Dassault Systemes Simulia Corp.

10）土方 勝一郎,今村 晃,杉山 達也,徳光 亮一,柳下 文雄,間瀬 辰也,井原 和 弘：3 次元弾塑性解析に基づく群杭地盤ばねの非線形特性，その 1 , その 2, その 3, 日本建築学会大会学術講演梗概集 構造 I, pp.631-636, 2008

11）土方 勝一郎,今村 晃,徳光 亮一,柳下 文雄,間瀬 辰也,井原 和弘 : 非線形 群杭係数に関する研究, その 1 , その 2 , 第 5 回日本地震工学会発表会, pp.178-181, 2007.11

12) Menétrey, Ph., and K. J. Willam, : Triaxial Failure Criterion for Concrete and its Generalization, ACI Structural Journal, vol. 92, pp.311-318, May/June 1995 


\title{
STUDIES ON THE FLUCTUATION CHARACTERISTICS \\ OF NON-LINEAR PILE GROUP COEFFICIENT
}

\section{Katsuichirou HIJIKATA* , Kazuhiro IHARA** , Fumio YAGISHITA** and Tatsuya MASE***}

\author{
* Prof., Shibaura Institute of Technology, Dr. Eng. \\ ** Tokyo Electric Power Services Co., Ltd., M. Eng. \\ *** Tokyo Electric Power Services Co., Ltd., Dr. Eng.
}

This paper presents the fluctuation characteristics of non-linear pile group coefficient. In this study, by evaluating the nonlinear influence coefficients between two piles, we have set up a non-linear pile group coefficient evaluation method which can evaluate nonlinearity of soil between and around piles. This method is based on the pile group coefficient expressions which we proposed for the elastic soil in the past. The fluctuation characteristics of non-linear pile group coefficient obtained with this method was confirmed that it corresponds well to that of the analysis results of the three-dimensional finite element method. Based on this knowledge, we elucidated the phenomenon that with pile head displacement increases, the value of the pile group coefficient increases at first, but this value starts to decrease in the later. As a result, the following characteristics are found out.

1. While the pile head displacement advances, nonlinearity due to local stress concentration of the soil in contact with the pile is preceded at the beginning. This acts in a direction to reduce the value of the non-linear influence coefficient, and to increase the value of non-linear pile group coefficient. In other words, the pile group effect reduces.

2. While the pile head displacement progresses further, stiffness degradation of whole soil arises in the later. This phenomenon is caused by the constraint effect of the piles to the whole soil which exists between and around piles. This acts in a direction to increase the value of the non-linear influence coefficient, and to reduce the value of non-linear pile group coefficients. In other words, the pile group effect increases.

3. Based on the characteristics described above, with the pile head displacement increasing, the non-linear pile group coefficient has the tendency to increase initially, and starts to decrease thereafter. The fluctuation characteristics of non-linear pile group coefficient are suppressed by such characteristics, and the value of non-linear pile group coefficient indicates to be relatively stable. 